Asian Social Work Journal (ASWJ), Volume 5, Issue 3, (page 1 - 11), 2020

DOI: https://doi.org/10.47405/aswj.v5i3.144

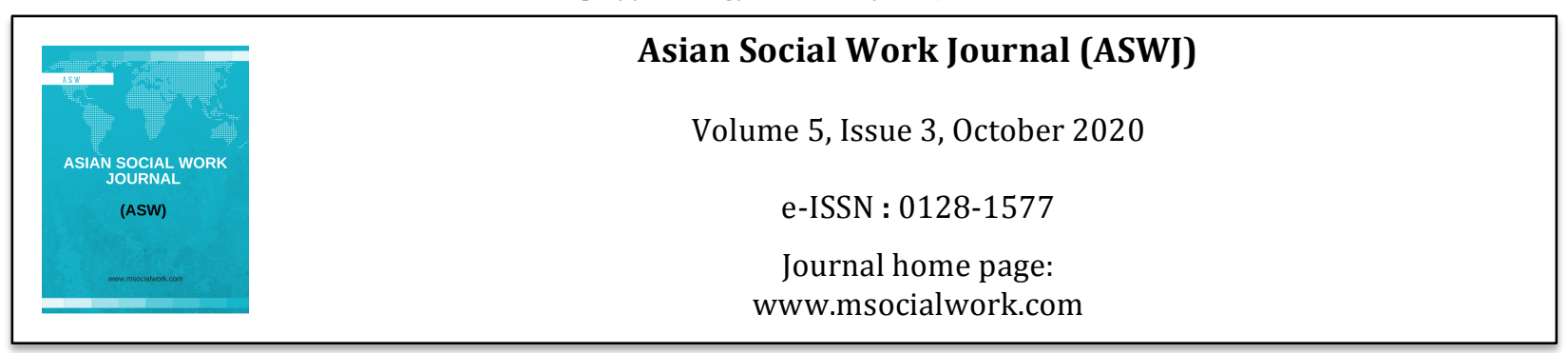

\title{
Early Childhood Education in Indonesia; A Primary Study on The Beneficiary Family of International Non-Government Organization
}

\author{
RR. Endah Sulistyaningsih ${ }^{1}$, Akiko Lahitani ${ }^{1}$ \\ ${ }^{1}$ Ministry of Social Affairs, Republic of Indonesia \\ Correspondence: Akiko Lahitani (lahitaniiko@gmail.com)
}

\begin{abstract}
This study aimed to examine the prevalence of parental understanding on the Early Childhood Education in the beneficiary family of programs held by the International Non-Government Organization. The research participants were the beneficiary family listed and provided by World Vision Indonesia and Child Fund Indonesia. The research used a quantitative research approach with self-administered survey instruments. The sample used for the present research is the beneficiary of the programmes that had been implemented by INGO, which includes 325 research participants located in Jakarta and Banten. The data collection took place on March 2020 using online media survey, with validity test have been done before the research instruments shared to all the participants. There were nine questions in the survey with nominal data value for every question rated on a 5-point Likert scale and the ratings summed into items corresponding to early childhood education. The analysis of the research instrument was using SPSS series 25 and the all of items being tested were valid with reliability statistic number 896 on Alpha Cronbach scale. The result shown that the child's education perceiving by the parents falls under the upper-class category with total score 16,341 out of 19,500 perfect score limit.
\end{abstract}

Keywords: early childhood education, parenting, international NGO, childhood development

\section{Introduction}

The United Nations Convention on the Rights of the Child is a legally binding international agreement setting out the civil, political, economic, social, and cultural rights of every child, regardless of their race, religion, or abilities. Every child has the right to survival, protection, and education, and to have their voice heard. The UNCRC claimed that states parties shall respect and ensure the fulfilment of children's rights as have been defined in the convention.

Education plays a vital role in the reproduction of cultural and economic capital. Differential access to education, and geographical variations in educational attainment, have thus been important themes in what might be considered inward-looking literature on geographies of education (Holloway, Hubbard, Jöns, \& Pimlott-Wilson, 2010). Nowadays, in the globalized world children have become a central issue in much attention of education, parenting, social changes, and development. Morrow (2011) argued that in past two decades have seen the importance of childhood as a stage that determining the adulthood. Family engagement in the education of their children viewed to be the most essential for the development of the children and parental support in education at home viewed to push better learning outcomes, children will be expected to get higher achievement at school (Henderson \& Mapp, 2020; Jeynes, 2005; Pomerantz, Moorman, \& Litwack, 2007; Reynolds \& Clement, 2005). 
DOI: https://doi.org/10.47405/aswj.v5i3.144

Children develop the foundations of emotional, mental, social, and communication skills during their first few years of their life that we call the 'golden age'. In the golden age period, there are many potentials can be developed rapidly in children learning experiences. The parental role in the early childhood education can turn into massive impact on children's behavior, parental involvement to be considered as stakeholder in the school community (Sapungan, 2014). There are parents that voluntarily engaged in school projects, take primary role in teaching and educating the children at home, assisting in children's homework, communicating constantly with the children discussing their day to day routines, take genuine interest on how the child getting on at their school and environment, paying a full attention on children strengths and weaknesses. However, there are parents who are quiet passive in their children's early years education and development.

The importance of the early childhood care and education can impact the range of various dimensions of the children's life, from social life to something specific such as STEM learning outcomes (Science, Technology, Engineering, and Math). Many researches have studied the importance of the early years' education for the child development; therefore, we still have to understand that education is rather contextual and cultural. (USAID, 2018). Although many parents are aware of the importance of early childhood education and how it determines the later life, they also often unaware of the science and research behind the involvement of parental intervention in the brain development and learning of the children that affecting academic achievement (Jeynes, 2016). Bronfenbrenner in Lara \& Saracostti, 2019 argued that parental involvement in children's education gives positive contribution to child's socioemotional and cognitive development. Parental involvement in children early childhood education can be different from one another, depend on the socio-economic background and educational level of the parents. Hence, the parental expectation towards children's education and what they will acquire in the future is very important. The parents' expectation can influence the attitude and the behaviour of the children (Berthelsen \& Walker, 2008).

In Indonesia, the context of early childhood education is still vague and viewed as a non-formal education. Some people still undervalued the early childhood education programmes, which that can be challenging issue on this global era. However, some parents are now aware of the importance of the early childhood education, that can be seen by the parents who send their kids to a legal institutions such Pendidikan Anak Usia Dini (PAUD) that regulated under Directorate General of Early Childhood Education of Ministry of Education and Culture. Currently, the government focus on PAUD are pointing to institution strengthening and enhancing service quality by targeting the character education to prepare young generation for the future.

Moreover, the policy content related on early childhood education has been developed in several country in Asia, including Indonesia. Statistics has shown (USAID, 2018) that Indonesia hold the highest number in the enrolment in ECE with 13.391.870, but still low in gross enrolment ratio in preprimary intake with $60.3 \%$ compared to Philippines that reached up to $100.4 \%$ gross enrolment ratio. This is due to the ECE policy in Indonesia that is non-compulsory, whereas ECE in India, Philippines, Vietnam, Tajikistan, Kyrgyzstan, is compulsory.

The development of Early Childhood Education can never be separated from the role and participation of the Non-Government Organizations (NGO) that called into attention both international and national level policies used to regulate the ECE. World Bank defines NGO as voluntary organizations that are non-profit and political-free interventions established to targeting the benefit of members or it is called grassroots organization (Taylor, 2019). The involvement of International NGO in maximizing the ECE programmes differ from one country to another. In Indonesia, we have known the Wahana Visi and Child Fund that have been pro-actively support the childhood education in the state.

The Wahana Visi Indonesia (WVI) is a social organization established in 1998 that works on making integrative changes for children, family, and community that live under poverty line. On their longterm development, the Wahana Visi Indonesia using area programme approach through operational offices that located in the assisted territory of WVI. Their programmes are focus on education, child protection, health, and family economic enhancement. Education is the most powerful tools to change the world, that WVI most priority is to give access to the quality education for the children. The 
Asian Social Work Journal (ASWJ), Volume 5, Issue 3, (page 1 - 11), 2020

DOI: https://doi.org/10.47405/aswj.v5i3.144

concern of the WVI is the children get access to nine years primary education that which includes 3 big areas: reading proficiency, writing proficiency, and life skills. One of their area of interest is the early childhood education or PAUD that being taken care by 146 qualified PAUD tutors.

Child Fund helps children live in deprivation, exclusion, and vulnerable to have their capacity to improve their lives and increasing opportunity so they will be becoming young adults, parents, and leaders who bring lasting and positive change in their community. Child Fund also focus on promoting society to participate in child protection and advancing the worth and rights of children. They work to resolve child problems with concentrated, collaborative efforts by the global community. There are six core issues that Child Fund focusing on children who live in poverty: child protection, emergency, health, education, early childhood development, and micro finance. Child Fund believes that educational and livelihood programmes are the key to escape the cycle of poverty. To fight for children's rights, education is playing a pivotal role by both in teaching children what they can and should expect from adults and showing adults the benefits of respecting their children's right. The ECD programmes by Child Fund aims to help the youngest children develop at their potential, enjoy good physical and mental health, live in supportive communities and be part of stable households that interact in nonviolent ways.

\section{Methodology}

\section{Research Approach}

This research used a descriptive quantitative data analysis. Quantitative methods emphasize objective measurements and the statistical mathematical, or numerical analysis of data collected through polls, questionnaires, and surveys (Babbie, 2013; Mujis, 2004). In quantitative research where researchers have obtained a larger sample to represent the population, the project can be used to generalise concepts more widely, predict future results, or investigate causal relationship. In this research, primary data collection was conducted to gather the information from the participants. Primary data is a type of data that being collected by the researcher for the first time, which is factual, original, and real-time data (Ajayi, 2017). There are various strategies to collect data using quantitative methods. According to Kabir (2016), type of quantitative data collections includes self-administered survey, paper-based questionnaires, observation, structured interview, and experiments/clinical trails.

The specific strengths of using a quantitative approach in this study are to enable a broader study, involve a greater number of subjects, enhance the generalisation of the results, employ prescribed procedures to ensure validity and reliability, and avoid personal bias by keeping a distance from participating subjects (Babbie, 2013; Manheim, Rich, Willnat, Brians, 2008). However, there are limitations in using quantitative approach, though it is efficient in working with large sample and can be used to test hypotheses statistically, but quantitative approach may miss contextual detail, the development of standard questions by researchers can lead to structural bias and false representation, where the data reflects the view of the researcher instead of the participating subject and the results provide less detail on behaviour, attitudes, and motivation (Neuman, 2011; Bernard, 2011). Slovin formula was being used to calculate the sample size with a margin error of 5 percent.

The data collection took place on March 2020 using online media survey, with validity test have been done before the research instruments shared to all the participants. The data collected from the participants in Jakarta area that registered as programmes' beneficiary of Wahana Visi Indonesia and Child Fund Indonesia. The sample used for the present research is the beneficiary of the programmes that had been implemented by International Non-Government Organization, namely Wahana Vision Indonesia and Childfund Indonesia which includes 325 research participants.

\section{Research Instrument}

Survey instrument applied in this study was questioner with closed-ended questions, the survey had done with the Google Form to minimize the direct contact with the research object due to the pandemic 


\section{Asian Social Work Journal (ASWJ), Volume 5, Issue 3, (page 1 - 11), 2020 DOI: https://doi.org/10.47405/aswj.v5i3.144}

Covid-19. The questionnaires were administered by the research team with the validity test before being employed. There were nine questions in the survey with nominal data value for every question rated on a 5-point Likert scale and the ratings summed into items corresponding to early childhood education. The analysis of the research instrument was using SPSS series 25 and the all of items being tested were valid with reliability statistic number 896 on Alpha Cronbach scale.

The table below is to show the full list of items for this study.

Table 1: Early Childhood Education Programs

\begin{tabular}{|c|c|c|c|c|c|c|}
\hline \multirow[t]{2}{*}{ NO } & \multirow[t]{2}{*}{ QUESTION } & \multicolumn{5}{|c|}{ ANSWER OPTIONS } \\
\hline & & 1 & 2 & 3 & 4 & 5 \\
\hline \multicolumn{7}{|c|}{ EARLY CHILDHOOD EDUCATION PROGRAMS } \\
\hline 1. & $\begin{array}{l}\text { According to you, how important the education is for the } \\
\text { children? }\end{array}$ & $\begin{array}{l}\text { not } \\
\text { important }\end{array}$ & $\begin{array}{l}\text { less } \\
\text { important }\end{array}$ & important & $\begin{array}{l}\text { quite } \\
\text { important }\end{array}$ & $\begin{array}{l}\text { very } \\
\text { important }\end{array}$ \\
\hline 2. & $\begin{array}{l}\text { How often do you include children in the educational programs } \\
\text { of this organization? }\end{array}$ & never & rarely & sometimes & often & always \\
\hline 3. & $\begin{array}{l}\text { Have there been any changes in children's learning motivation } \\
\text { after attending an educational program from this organization? }\end{array}$ & not visible & $\begin{array}{l}\text { less } \\
\text { visible }\end{array}$ & visible & $\begin{array}{c}\text { quite } \\
\text { visible }\end{array}$ & $\begin{array}{l}\text { very } \\
\text { visible }\end{array}$ \\
\hline 4. & $\begin{array}{l}\text { Are there any expectations from parents that their children will } \\
\text { have a higher education? }\end{array}$ & not visible & $\begin{array}{l}\text { less } \\
\text { visible }\end{array}$ & visible & $\begin{array}{c}\text { quite } \\
\text { visible }\end{array}$ & $\begin{array}{l}\text { very } \\
\text { visible }\end{array}$ \\
\hline 5. & $\begin{array}{l}\text { Do children like the educational programs organized by this } \\
\text { organization? }\end{array}$ & dislike & likely & like & quite like & very like \\
\hline 6. & $\begin{array}{l}\text { Have you ever received support tools for schools from an } \\
\text { educational program organized by this organization? }\end{array}$ & never & rarely & sometimes & often & always \\
\hline 7. & $\begin{array}{l}\text { Does your child always participate in teaching and learning } \\
\text { activities at school or other learning places? }\end{array}$ & no & rarely & sometimes & often & always \\
\hline 8. & How often do you consult about child education? & never & rarely & sometimes & often & always \\
\hline 9. & $\begin{array}{l}\text { Do you teach your child about good and bad behavior in } \\
\text { learning? }\end{array}$ & never & rarely & sometimes & often & always \\
\hline 10. & Do you pay attention to the child's educational environment? & Never & Rarely & Sometimes & Often & Always \\
\hline 11. & Do you give your child an understanding of a clean environment? & Never & Rarely & Sometimes & Often & Always \\
\hline 12. & $\begin{array}{l}\text { Do you provide information about sexual education to children } \\
\text { from an early age? }\end{array}$ & Never & Rarely & Sometimes & Often & Always \\
\hline
\end{tabular}

\section{Results and Discussion}

\section{Preliminary Analysis}

Calculation of the average score for every question has been done to get description on the participants understanding in regards of early childhood education. Categorization has been regulated for the result of this study, the researcher has classified the score into three categories with the set interval width, namely lower category, middle category, and upper category. A formula had been used to calculate the interval width to get spread evenly for every category.

$$
\boldsymbol{i}=\begin{array}{cll}
\boldsymbol{R} & \boldsymbol{i} & : \text { Interval width } \\
\mathbf{K} & \boldsymbol{R} & : \text { Range } \\
\mathbf{K} & & : \text { Number of class }
\end{array}
$$

To get to the interval value, the Range need to be calculated first by subtracting the lowest value from the highest value. On this study, the highest value is 19,500 subtracted by 3,900, it gets 15,600 for Range value. From the set formula, it gets interval width value at 5,200.

The interval width was needed to measure the value in each category, with the lowest limit score of this early childhood education is 3,900 then added by the interval width. The categories are described as the lower category score ranges from 3,900 to 9,100 , the middle category score ranges from 9,101 to 14,300 , and the upper category score ranges from 14,301 to 19,500 . From the preliminary analysis, this study measured the total value score falls at 16,341 which shown 
Asian Social Work Journal (ASWJ), Volume 5, Issue 3, (page 1 - 11), 2020

DOI: https://doi.org/10.47405/aswj.v5i3.144

that the responds of the respondent towards the ECE implemented by the WVI and Child Fund Indonesia is quite high.

Table 2: According to you, how important the education is for the children?

\begin{tabular}{llllll}
\hline & & Frequency & Percent & $\begin{array}{l}\text { Valid } \\
\text { Percent }\end{array}$ & $\begin{array}{l}\text { Cumulative } \\
\text { Percent }\end{array}$ \\
\hline Valid & 3 & 16 & 4,9 & 4,9 & 4,9 \\
& 4 & 10 & 3,1 & 3,1 & 8,0 \\
& 5 & 299 & 91,4 & 92,0 & 100,0 \\
& Total & 325 & 99,4 & 100,0 & \\
Missing & System & 2 &, 6 & & \\
Total & & 327 & 100,0 & & \\
\hline
\end{tabular}

The table 2 above is describing the result from the question "According to you, how important the education is for the children?". From the 327 research participants, no one neither given answer for the choice "not important" (1) nor for the choice "less important" (2). The table shown that 16 participant or $4.9 \%$ have chosen "important" (3), a number of 10 participants had answered for "quite important" (4) that makes to $3.1 \%$, and a grand number of 325 participants that makes up to $91,4 \%$ agreed to the choice that education for children is "very important" (5). Therefore, the table 2.0 also shown that there is missing value of $0.6 \%$ that from identification from the spreadsheet, the 2 participants had not given any answer to this particular question. The total score for this question is 1,583 out of 1625 of perfect score with the mean value of choice is 4.87 .

Table 3 describes us for the answer for the question "How often do you include children in the educational programs of this organization?". From the 327 respondents, 4 people answer 'never' (1) that makes up to $1.2 \%, 17$ people have answered 'rarely' (2) that makes up to $5.2 \%$, a group of 50 people have answered for 'sometimes' that makes up to $15.3 \%$. Furthermore, a big number of 161 people have answered for 'often' (4) given up to $49.2 \%$ and 93 people have answered for 'always' (5) that given up to $28.4 \%$ out of $100 \%$. This table shown that majority of parents are aware to the importance of involving their children in the educational programs that have held by the International Non-Government Organizations, only small chunk of the respondents need further socialization of the essence to have their children participate in the educational programs. The total score for this second question is 1,297 out of 1625 of perfect score with the mean value is 3.99 .

Table 3: How often do you include children in the educational programs of this organization?

\begin{tabular}{llllll}
\hline & Frequency & Percent & $\begin{array}{l}\text { Valid } \\
\text { Percent }\end{array}$ & $\begin{array}{l}\text { Cumulative } \\
\text { Percent }\end{array}$ \\
\hline Valid & 1 & 4 & 1,2 & 1,2 & 1,2 \\
& 2 & 17 & 5,2 & 5,2 & 6,5 \\
& 3 & 50 & 15,3 & 15,4 & 21,8 \\
& 4 & 161 & 49,2 & 49,5 & 71,4 \\
& 5 & 93 & 28,4 & 28,6 & 100,0 \\
& Total & 325 & 99,4 & 100,0 & \\
Missing & System & 2 &, 6 & & \\
Total & & 327 & 100,0 & & \\
\hline
\end{tabular}

Table 4 describes us the answer for the question "Have there been any changes in children's learning motivation after attending an educational program from this organization?". The answers that parents have given mostly affirmative. Only 9 respondents have answered 'not visible' (1) or make up to 2.8\%, another 10 respondents have answered 'less visible' (2) or 3.1\%. Both the answers 'visible' (3) and 'quite visible' (4) gained 106 respondents or $32.4 \%$ and 107 respondents or $32.7 \%$ respectively. Not so far different from the previous questions, 93 respondents have answered 'very visible' (5) or makes up to $28.4 \%$. This question had convinced that the attended programs have make an impact on children 


\section{Asian Social Work Journal (ASWJ), Volume 5, Issue 3, (page 1 - 11), 2020 DOI: https://doi.org/10.47405/aswj.v5i3.144}

behaviour and have shown several changes. The total score for this second question is 1,240 out of 1625 of perfect score with the mean value is 3.81 .

Table 4: Have there been any changes in children's learning motivation after attending an educational program from this organization?

\begin{tabular}{llllll}
\hline & Frequency & Percent & Valid Percent & $\begin{array}{l}\text { Cumulative } \\
\text { Percent }\end{array}$ \\
\hline Valid & 1 & 9 & 2,8 & 2,8 & 2,8 \\
& 2 & 10 & 3,1 & 3,1 & 5,8 \\
& 3 & 106 & 32,4 & 32,6 & 38,5 \\
& 4 & 107 & 32,7 & 32,9 & 71,4 \\
& 5 & 93 & 28,4 & 28,6 & 100,0 \\
& Total & 325 & 99,4 & 100,0 & \\
Missing & System & 2 &, 6 & & \\
Total & & 327 & 100,0 & & \\
\hline
\end{tabular}

Table 5 presents us question to get to know the parents' expectation in regard on their child getting on to a higher education by asking them "Are there any expectations from parents that their children will have a higher education?". Surprisingly there is only one respondents answered for 'not visible' (1) that makes it only $0.3 \%$ and none of the respondents answered for 'less visible' (2) and 84 respondents have answered 'visible' (3) that makes up to $25.7 \%$. There is a huge leap on the $4^{\text {th }}$ and $5^{\text {th }}$ answers that made up to a total 240 respondents out of 325 respondents. This is very interesting as 6 respondents answered for 'quite visible' (4) while 234 respondents answered for 'very visible' (5), that made $1.8 \%$ and $71.6 \%$ respectively. We can assume that most of the parents are in a great expectation of their children will be getting on to a higher level of education, given the fact only one of them that do not expect the child to go on further education. The total score for this second question is 1,447 out of 1625 of perfect score with the mean value is 3.46 .

Table 5: Are there any expectations from parents that their children will have a higher education?

\begin{tabular}{llllll}
\hline & Frequency & Percent & Valid Percent & $\begin{array}{l}\text { Cumulative } \\
\text { Percent }\end{array}$ \\
\hline Valid & 1 & 1 &, 3 &, 3 &, 3 \\
& 3 & 84 & 25,7 & 25,8 & 26,2 \\
& 4 & 6 & 1,8 & 1,8 & 28,0 \\
& 5 & 234 & 71,6 & 72,0 & 100,0 \\
& Total & 325 & 99,4 & 100,0 & \\
Missing & System & 2 &, 6 & & \\
Total & & 327 & 100,0 & & \\
\hline
\end{tabular}

Table 6 describes the answer for the question "Do children like the educational programs organized by this organization?". No respondents had answered for 'dislike' (1) that makes only four answers represent the children's view on how the programs have impacted the child's perception. Only five respondents or $1.5 \%$ have answered for 'likely' (2) and 150 respondents have answered for 'like' (3) or $45.9 \%$. To our surprise the number for the answer 'quite like' (4) dropped to meet only 55 respondents or $16.8 \%$ and 115 respondents or $35.2 \%$ have answered for 'very like' (5). The distribution of the answers was not even on this subject of matter, given analysis that there was different perspective on how the educational programs delivered to the children of beneficiary of the organization's programs. The total score for this second question is 1,255 out of 1625 of perfect score with the mean value is 3.86 . 
Asian Social Work Journal (ASWJ), Volume 5, Issue 3, (page 1 - 11), 2020

DOI: https://doi.org/10.47405/aswj.v5i3.144

Table 6: Do children like the educational programs organized by this organization?

\begin{tabular}{llllll}
\hline & Frequency & Percent & Valid Percent & $\begin{array}{l}\text { Cumulative } \\
\text { Percent }\end{array}$ \\
\hline Valid & 2 & 5 & 1,5 & 1,5 & 1,5 \\
& 3 & 150 & 45,9 & 46,2 & 47,7 \\
& 4 & 55 & 16,8 & 16,9 & 64,6 \\
& 5 & 115 & 35,2 & 35,4 & 100,0 \\
& Total & 325 & 99,4 & 100,0 & \\
Missing & System & 2 &, 6 & & \\
Total & & 327 & 100,0 & & \\
\hline
\end{tabular}

Table 7 describes the answer for the question "Have you ever received support tools for schools from an educational program organized by this organization?". From the result above, 32 respondents that equal to $9.8 \%$ have answered 'never' (1), slightly different with the answer 'rarely' (2) that gained 28 respondents that equal to $8.6 \%$. A fair amount of 77 respondents have answered 'sometimes' (3) that equal to $23.5 \%$. A number of 133 respondents have answered 'often' (4) that equal to $40.7 \%$ made the most answered on this question. Second most answered is 'always' that have 55 respondents that equal to $16.8 \%$. From this table of result, there is quite fair distribution of answer for each option, thought it still affirmative, nevertheless $18.4 \%$ respondents identified tools support from the educational program were not sufficiently distributed. The total score for this second question is 1,126 out of 1625 of perfect score with the mean value is 3.47 .

Table 7: Have you ever received support tools for schools from an educational program organized by this organization?

\begin{tabular}{llllll}
\hline & & Frequency & Percent & Valid Percent & $\begin{array}{l}\text { Cumulative } \\
\text { Percent }\end{array}$ \\
\hline Valid & 1 & 32 & 9,8 & 9,8 & 9,8 \\
& 2 & 28 & 8,6 & 8,6 & 18,5 \\
& 3 & 77 & 23,5 & 23,7 & 42,2 \\
& 4 & 133 & 40,7 & 40,9 & 83,1 \\
& 5 & 55 & 16,8 & 16,9 & 100,0 \\
& Total & 325 & 99,4 & 100,0 & \\
Missing & System & 2 &, 6 & & \\
Total & & 327 & 100,0 & & \\
\hline
\end{tabular}

Table 8 describes the distribution of answer for the question "Does your child always participate in teaching and learning activities at school or other learning places?". As we have expected that the answers spread shown that the most answered option was 'always' (5) for a number of 143 respondents that made $43.7 \%$ of total respondents. Then followed by 96 respondents have answered for 'often' (4) that made it $29.4 \%$. Furthermore, 55 respondents have answered for 'sometimes' (3) that made it to $16.8 \%$. There were also respondents that shown based on this research had their children did not participate on the teaching and learning activities, 10 respondents have answered 'rarely' (2) and 20 respondents have answered ' $n o$ ' (1) that made to $3.1 \%$ and $6.1 \%$ respectively. The total score for this second question is 1,304 out of 1620 of perfect score with the mean value is 4.03 .

Table 8: Does your child always participate in teaching and learning activities at school or other learning places?

\begin{tabular}{llllll}
\hline & & Frequency & Percent & Valid Percent & $\begin{array}{l}\text { Cumulative } \\
\text { Percent }\end{array}$ \\
\hline Valid & 1 & 20 & 6,1 & 6,2 & 6,2 \\
& 2 & 10 & 3,1 & 3,1 & 9,3 \\
& 3 & 55 & 16,8 & 17,0 & 26,2 \\
\hline
\end{tabular}


DOI: https://doi.org/10.47405/aswj.v5i3.144

\begin{tabular}{llllll}
\hline & 4 & 96 & 29,4 & 29,6 & 55,9 \\
& 5 & 143 & 43,7 & 44,1 & 100,0 \\
& Total & 324 & 99,1 & 100,0 & \\
Missing & System & 3 &, 9 & & \\
Total & & 327 & 100,0 & & \\
\hline
\end{tabular}

Table 9 describes the distribution of answers for the question "How often do you consult about child education?". From the table above, 8 respondents have answered 'never' (1) that makes up to $2.4 \%$, and 12 respondents have answered for 'rarely' (2) that makes up to $3.7 \%$. As for the answer 'sometimes' (3) there is 95 respondents have answered and that makes up to $29.1 \%$. The most answered option is 'often' (4) that gained 152 respondents and equal to $46.5 \%$, this showed that majority of respondents have understood of the benefit from having consultation about their child's education by having regular consultation. The last option for 'always' (5) has 58 respondents answered that makes up to $17.7 \%$ in total, thought this is not the most significant answered, the research have shown that the responds for this subject matter were affirmative. The total score for this second question is 1,215 out of 1625 of perfect score with the mean value is 3.74 .

Table 9: How often do you consult about child education?

\begin{tabular}{llllll}
\hline & & Frequency & Percent & Valid Percent & $\begin{array}{l}\text { Cumulative } \\
\text { Percent }\end{array}$ \\
\hline Valid & 1 & 8 & 2,4 & 2,5 & 2,5 \\
& 2 & 12 & 3,7 & 3,7 & 6,2 \\
& 3 & 95 & 29,1 & 29,2 & 35,4 \\
& 4 & 152 & 46,5 & 46,8 & 82,2 \\
& 5 & 58 & 17,7 & 17,8 & 100,0 \\
& Total & 325 & 99,4 & 100,0 & \\
Missing & System & 2 &, 6 & & \\
Total & & 327 & 100,0 & & \\
\hline
\end{tabular}

Table 10 describes the distribution of answer for the question "Do you teach your child about good and bad behavior in learning?". Only 3 respondents have answered for 'never' (1) that makes up to $0.9 \%$ and there was none of the respondents have answered for 'rarely' (2). Moreover, as small as 2 people have answered for 'sometimes' (3) that makes up to $0.6 \%$. The result for the answers of this subject matter confirmed that majority of the parents have taught the children a lesson about good and bad behavior. For the option 'often' (4) gained 62 respondents that equal to 19\%, leave the option 'always' (5) very prominent with 258 respondents that makes up to $78.9 \%$ in total. Statistically, this result shown that the parents have accompanied by the believe that teaching their child good value rather a necessary. The total score for this second question is 1,547 out of 1625 of perfect score with the mean value is 4.76 .

Table 10: Do you teach your child about good and bad behavior in learning?

\begin{tabular}{llllll}
\hline & & Frequency & Percent & Valid Percent & $\begin{array}{l}\text { Cumulative } \\
\text { Percent }\end{array}$ \\
\hline Valid & 1 & 3 &, 9 &, 9 &, 9 \\
& 3 & 2 &, 6 &, 6 & 1,5 \\
& 4 & 62 & 19,0 & 19,1 & 20,6 \\
& 5 & 258 & 78,9 & 79,4 & 100,0 \\
& Total & 325 & 99,4 & 100,0 & \\
Missing & System & 2 &, 6 & & \\
Total & & 327 & 100,0 & & \\
\hline
\end{tabular}

Table 11 describes the distribution of answer for the question "Do you pay attention to the child's educational environment?". No respondent had answer for 'never' (1) while there was 2 respondents had chosen 'rarely' (2) that makes up to 0.6 percent, followed by the respondents who had chosen 
DOI: https://doi.org/10.47405/aswj.v5i3.144

'sometimes' (3) that makes up to 0.9 percent. For the choice of answer 'often' (4) made by 47 respondents that measured to 14.4 percent. The highest number for choice of answer is 'always' that responded by 273 people that makes up to 83.5 percent. The total score for this second question is 1,566 out of 1625 of perfect score with the mean value is 4.81 .

Table 11: Do you pay attention to the child's educational environment?

\begin{tabular}{llllll}
\hline & & Frequency & Percent & Valid Percent & $\begin{array}{l}\text { Cumulative } \\
\text { Percent }\end{array}$ \\
\hline Valid & 2 & 2 &, 6 &, 6 &, 6 \\
& 3 & 3 &, 9 &, 9 & 1,5 \\
& 4 & 47 & 14,4 & 14,5 & 16,0 \\
& 5 & 273 & 83,5 & 84,0 & 100,0 \\
& Total & 325 & 99,4 & 100,0 & \\
Missing & System & 2 &, 6 & & \\
Total & & 327 & 100,0 & & \\
\hline
\end{tabular}

Table 12 describes the distribution of answer for the question "Do you give your child an understanding of a clean environment?". There were 3 respondents that answered for the choice 'never' (1) that makes up to 0.9 percent that followed by 1 respondent who had chosen 'rarely' (2) that only contributes to 0.3 percent. Another 4 respondents had answered for 'sometimes' (3) that makes up to 1.2 percent and second majority of respondents had answered 'often' (4) which makes up to 15.9 percent. A big number of respondents had answered for 'always' (5) that is 264 people which measured up to 80.7 percent. The total score for this second question is 1,545 out of 1620 of perfect score with the mean value is 4.76 .

Table 12: Do you give your child an understanding of a clean environment?

\begin{tabular}{llllll}
\hline & & Frequency & Percent & Valid Percent & $\begin{array}{l}\text { Cumulative } \\
\text { Percent }\end{array}$ \\
\hline Valid & 1 & 3 &, 9 &, 9 &, 9 \\
& 2 & 1 &, 3 &, 3 & 1,2 \\
& 3 & 4 & 1,2 & 1,2 & 2,5 \\
& 4 & 52 & 15,9 & 16,0 & 18,5 \\
& 5 & 264 & 80,7 & 81,5 & 100,0 \\
& Total & 324 & 99,1 & 100,0 & \\
Missing & System & 3 &, 9 & & \\
Total & & 327 & 100,0 & & \\
\hline
\end{tabular}

Table 13 describes the distribution of answer for the question "Do you provide information about sexual education to children from an early age?". We can see the pattern here that the distribution of the answer is quite even. There were 35 respondents have answered 'never' (1) that contributes to 10.7 percent of the population. Then it is followed by the respondents who answered 'rarely' with the number of 13 people that makes up to 4.0 percent. 78 respondents had chosen 'sometimes' (3) which measured to 23.9 percent, there is slightly different with the choice of answer 'often' that chose by 74 respondents which measured to 22.6 percent. 125 respondents have answered for 'always' (5) that measured to 38.2 percent. Though the respondents who answered they are always giving sexual education to the child was not a great number, but it shown that the community have understand the importance of early sexual education for the children. The total score for this second question is 1,216 out of 1625 of perfect score with the mean value is 3.75 .

Table 13: Do you provide information about sexual education to children from an early age?

\begin{tabular}{|c|c|c|c|c|c|}
\hline & & Frequency & Percent & Valid Percent & $\begin{array}{l}\text { Cumulative } \\
\text { Percent }\end{array}$ \\
\hline Valid & 1 & 35 & 10,7 & 10,8 & 10,8 \\
\hline
\end{tabular}


Asian Social Work Journal (ASWJ), Volume 5, Issue 3, (page 1 - 11), 2020

DOI: https://doi.org/10.47405/aswj.v5i3.144

\begin{tabular}{llllll}
\hline & 2 & 13 & 4,0 & 4,0 & 14,8 \\
& 3 & 78 & 23,9 & 24,0 & 38,8 \\
& 4 & 74 & 22,6 & 22,8 & 61,5 \\
& 5 & 125 & 38,2 & 38,5 & 100,0 \\
& Total & 325 & 99,4 & 100,0 & \\
Missing & System & 2 &, 6 & & \\
Total & & 327 & 100,0 & & \\
\hline
\end{tabular}

From the result of this study, we can draw a $\mathrm{n}$ understanding that the early childhood education and development is given quite good concern from the parents of the beneficiary family. Most of the parents have shown that they always be there for the children to assist the learning process. Interestingly, the parents demonstrated agreeable attitudes towards children's education environment. This brought a discourse that the parents always check and make sure that their children given the best educational environment as possible. However, from the result there is smaller number of parents admitted that the children only sometimes liking the programs held by the INGO, furthermore the supporting tools for children involved in the program was not evenly distributed. Moreover, Parental perceptive towards educational consultation considered to be lower, that most parents seem not taking serious consideration of having consultation in the matter of early childhood education process. The last question of the survey was the sexual education given to the children by the parents. As part of childhood development, sexual education cannot be eradicated from the learning process that certainly every parent is responsible to assist. Sexual education needs to be given more serious thoughts as this could be the preventive action against child sexual abuse.

\section{Conclusion}

The prevalence of parental understanding in regard to Early Childhood Education in the beneficiary family of International Non-Government Organization concluded to be good. This is shown with the score that considered to be high and falls in the upper category. Despite the difference of mean and total score in each question, the study found that the programs related to early childhood education and development held and organized by the WVI and Child fund Indonesia considered to be very good. The parents demonstrated sufficient and agreeable knowledge about early childhood education. As part of the Sustainable Development Goals, education is one of prominent agenda to increasing the standard of life of the children and eradicating the poverty. Starting with the aerial programs, every child in Indonesia can get access to early childhood education to prepare young people to be productive and become competent generation in global world.

Through this survey research, it acts as evaluation process for the INGO working with children and family in Indonesia to improve and flourishing their programs. From this variable of research, we can summarize that the WVI and Child fund Indonesia had a big impact on the early childhood education. Though, some aspects are needing to be improve such as more parental education on the importance of giving children proper sexual education as part of preventive action against child sexual harassment and abuse. Hence current research is a univariate study, further research needed to be done to focus on to the correlation between family socio-economic background with the development of child's education. Likewise, multivariate research is being recommended for future research.

\section{Acknowledgment}

This research is fully supported by the Planning Bureau of Ministry of Social Affairs, Republic of Indonesia. The study cannot be held without the commitment of the research team and support from Australian Award Indonesia, so the research is possible to be done in a mannerly time. This research is in respect to the International Non-Government Organization that have working along the Ministry of Social Affairs to actualize programs for children and family. 


\section{References}

Ajayi, V. O. (2017). Primary Sources of Data and Secondary Sources of Data. DOI: 10.13140/RG.2.2.24292.68481

Babbie, E. R. (2013). The Basics of Social Research. $6^{\text {th }}$ ed. Boston: Cengage Learning. ISBN: 9781133594147

Bernard, H. R. (2011). Research Methods in Anthropology: Qualitative and Quantitative Approaches. $5^{\text {th }}$ ed. Maryland: Rowman Altamira. ISBN: 9780759112438

Berthelsen, Donna., \& Walker, Sue. (2008). Parents' Involvement in Their Children's Education. Australian Institute of Family Studies, No. 79. booklet_english - UNCRCEnglish_0.pdf. (n.d.). Retrieved

from http://www.childrensrights.ie/sites/default/files/submissions_reports/files/UNCRCEnglish_0.pdf

Henderson, A. T., \& Mapp, K. L. (2002). A New Wave of Evidence: The Impact of School, Family, and Community Connections on Student Achievement. Austin, TX: South-West Educational Development Laboratory.

Holloway, S. L., Hubbard, P., Jöns, H., \& Pimlott-Wilson, H. (2010). Geographies of education and the significance of children, youth and families. Progress in Human Geography, 34(5), 583600. https://doi.org/http://dx.doi.org.ucd.idm.oclc.org/10.1177/0309132510362601

Jeynes, W. H. (2005). A Meta-Analysis of the Relation of Parental Involvement to Urban Elementary School Student Academic Achievement. Urban Education, 40, 237-269.

Kabir, Syed Muhammad Sajjad. (2016). Methods of Data Collection. Curtin University.

Manheim, J. B., Rich, R. C., Willnat, L. \& Brians, C. L. (2008). Empirical Political Analysis: Quantitative and Qualitative Research Methods. $7^{\text {th }}$ ed. New York: Pearson Education.

Morrow, V. (2011). Understanding children and childhood. Retrieved from http://epubs.scu.edu.au/cgi/viewcontent.cgi?article=1027\&context=ccyp pubs

Neuman, W. L. (2011). Social Research Methods: Qualitative and Quantitative Approaches. $7^{\text {th }}$ ed. Boston: Pearson.

Pomerants, E. M., Moorman, E. A., \& Litwack, S. D. (2007). The How, Whom, and Why of Parents' involvement in Children's Academic Lives. Review of Educational Research, 77(3), 373-410.

Reynolds, A., \& Clements, M. (2005). Parental Involvement and Children's School Success. In Donna Berthelsen, \& Sue Walker, Parents' Involvement in Their Children's Education (pp. 40). Australian Institute of Family Studies.

Sapungan, Ronel Mondragon. (2014). Parental Involvement in Child's Education: Importance, Barriers, and Benefits. Asian Journal of Management Science \& Education, Vol. 3(2). ISSN: 2186-845X

Taylor, Laura. (2019). The Role of Non-Governmental Organizations in Global Education: A Case Study on Sub-Saharan Africa. Honors Theses. 1154. https://egrove.olemiss.edu/hon_thesis/1154

Y., Sitabkhan., J., Spratt., E., Dombrowski., \& T., Weatherholt. (2018). All Children Reading-Asia (ACR-Asia), Early Childhood Education: Considerations for Programming in Asia. North Carolina: USAID 